\begin{tabular}{ll}
\hline 原 \\
\hline
\end{tabular}

\title{
大量の煮物における煮汁の対流についての研究
}

\section{A Study on the Convection of Liquid in the Cooking Pan and the Osmotic Pressure of Foods}

\author{
賢明女子学院短大 (Kenmei Women's Junior College) \\ 片山喜美子 (Kimiko Katayama) \\ 立正女子短大 (Rissho Women's Junior College) \\ 斎 藤 貴美子 (Kimiko Saito) \\ 立正女子大学 (Rissho Women's College) \\ 高木 和 男 (Kazuo Takagi)
}

\begin{abstract}
Of Japanese cooking methods, boiling and stewing are usually applied in mass-feeding, but there are very few data on heat transference. Most troubles occur in designing the heating apparatus or improvement of cooking methods. Beside these, there are destroying the shape of food is destroyed during the boiling in the cooking pan. This phenomenon seems to be partly concerned with the osmotic pressure of foods.

The results obtained were as follows:

1. There was no significant difference between fresh water and the $3 \%$ starch solution in the convection of heat.

2. Solid substances such as solid·foods, did not disturb normal convection of liquid.

3. The lid of the cooking pan can maintain temperature of the space between the liquid surface and the lid as same as the upper-layer temperature of the water.
\end{abstract}

\section{I 緒言}

著者らは, 従来集団給食における調理について研究し, 報告1)を重ねてきたが，今回は煮る調理に怙ける対 流と，食品の浸透圧とについて報告する。煮るという調理は，日本食においては最もしばしば行なわれる調理 法であるが, この調理の特徴である, 液体の対流についての研究は余り行なわれていない。煮物においての煮 汁の対流は，煮る調理の伝熱の主体をなするので，これは惹汁の粘度，食品と煮汁の比率などにより異なると 思われる。これらの関係についての実験を報告する。

\section{II 加熱時における鍋内液体の温度分布変化についての実験}

実験は小規模の調理についてのものと，大鍋を用いる大量調理についてのものの 2 種に別けられる。

A）小鍋を用いる小規模調理についての実験

(1) 実験方法

a. 使用した鍋と熱源 : 直径 $20 \mathrm{~cm}$ の市販アルミ製両手鍋を用いた。水深 $5.5 \mathrm{~cm}$ とした場合の水量は 
$1,600 \mathrm{~m} l$ であった。

b. 温度測定： 6 点切換付熱電対（池田製作所製）を使用し，その感応部を鍋の中心部に上下方向に 4 点配 置したが，その位置を示せば図 1 の如くである。

鍋の底から蓋の下面まで $9.5 \mathrm{~cm}$ あるが, 液体の深さを $5.5 \mathrm{~cm}$ としたから, 蓋下の空間は $4 \mathrm{~cm}$ である。熱電対の感 応部(1)はこの空間の上下方向の中間に, (2)は液面下 $0.5 \mathrm{~cm}$ に, (3)は液面下 $2.5 \mathrm{~cm}$ に, (4)は液面下 $5.0 \mathrm{~cm}$, すなわち底 から $0.5 \mathrm{~cm}$ のところに配置した。温度の観測は各点を切 換えて行なうため 1 力所 30 秒を必要とし, 各点の観測時刻

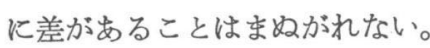

c. 粘度ある煮汁の作製：煮汁に粘度を附与するために

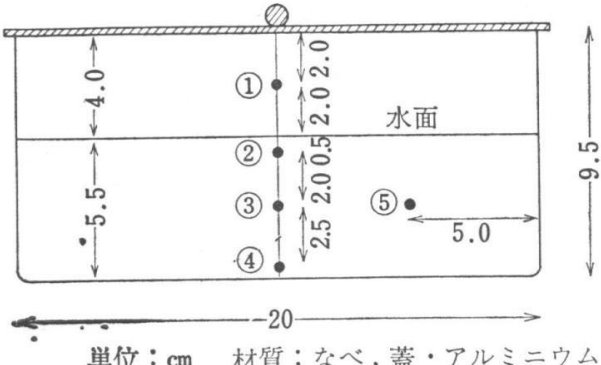

図 1 小鍋実験, 熱電対感応部の位置 は市販上質片栗粉を水溶液に対し，1\%，3\%，5\%加光て加熱溶解して，放冷後実験に用いた。 粘度の測定は KK. 東京計器製造所製, BM 型粘度計を用いた。

d. 食品の代りに用いた固形物について：食品を煮る場合の状況を実験するため，水中に食品に代るべさ固 形物を入れて実験する必要がある。このような固形物としての必要な条件は, 物質が溶出しないこと, 比重が 食品のそれに近いこと, すなわち, 水に近く, 少し重いことである。このような条件を具備する固形物とし て, 多数の物質について実験した後, 小型鍋の調理の場合にはコンニャクが最も適当であることを知ったの で,これを $2.5 \mathrm{~cm}$ 角に切ったものを用いた。

(2) 実験の条件

実験は次のような条件について行なった。

\begin{tabular}{|c|c|c|c|}
\hline 実験番号 & 液体捄よび内容物 & 全容量 $(\mathrm{m} l)$ & 実験回数 \\
\hline No. 1 & 水道水 & 1,600 & 6 \\
\hline No. 2 & でん粉 $1 \%$ 溶液 & 1,600 & 2 \\
\hline No. 3 & でん粉 $3 \%$ 溶液 & 1,600 & 2 \\
\hline No. 4 & でん粉 $5 \%$ 溶液 & 1,600 & 2 \\
\hline No. 5 & コンニャク $1:$ 水 1 （容量比） & 1,600 & 2 \\
\hline No. 6 & コンニャク $1.5:$ 水 1 （容量比） & 1,600 & 2 \\
\hline No. 7 & コンニャク $2.0:$ 水 1 （容量比） & 1,600 & 2 \\
\hline No. 8 & コンニャク $2.5:$ 水 1 （容量比） & 1,600 & 2 \\
\hline No. 9 & コンニャク $3.0:$ 水 1 （容量比） & 1,600 & 2 \\
\hline
\end{tabular}

(3) 実験結果

a. 加熱される水溶液の粘度と容器内の温度分布に ついて:実験番号としては No. 1 から No. 4 までの 実験である。実験に用いた溶液の粘度は表 1 の如きも のであった。

実験に用いたでん粉 $1 \%$ 溶液は，しばしば一般に用 いられている, くず湯の濃度に相当し，5\%溶液は, 吉野煮, あんかけ用のくず溶液の濃度に相当する。
表 1 でん粉溶液の粘度

\begin{tabular}{|c|c|c|c|}
\hline \multirow{2}{*}{ 濃 度 } & \multicolumn{3}{|c|}{ 温 度 } \\
\hline & $30^{\circ} \mathrm{C}$ & $95^{\circ} \mathrm{C}$ & 料 理 例 \\
\hline $1 \%$ & $7 \mathrm{cP}$ & $5 \mathrm{cP}$ & くず湯 \\
\hline $3 \%$ & $68 \mathrm{cP}$ & $38 \sim 55 \mathrm{cP}$ & 吉野煮 \\
\hline $5 \%$ & $1,140 \mathrm{cP}$ & $450 \sim 500 \mathrm{cP}$ & あんかけ \\
\hline
\end{tabular}


鍋内の温度上升の状熊を測定した結果は図 2 〜 5 の如くである。すなわち真水の場 合 (庹 2 ), 鍋の 底部の水と上層部の水との温度は加熱 10 分の頃か ら， $4^{\circ} \mathrm{C}$ の差を以って上層部の方がむしろ高く, 約18分後に至って, 両者の差はなくなる。また下層 部は上層部に約 1 分遅れて同一温度に達することが わかる。

さらに鍋の蓋と水面との間に残った空間の温度 は, 加熱後 4 〜 10分の間はかなりの温度差を水温と の間に示すが，その後徐々に温度差はちぢまり， 20 分後には水温と同一の温度に達することがわか る。

本実験の加熱方法の下では，加熱後約 11 分まで は, 蓋下部は鍋の上層より約 1 分 30 秒遅れて同一温 度に達するのであるが，加熱後14分に至れば30秒の 遅れで液の上層部と同一温度になる。

以.上のことから，鍋の蓋がよく閉じていれば熱伝 導率つ高いアルミニウムの蓋の場合にも, 煮物の液 面から露出した部分も十分に加熱されるということ がわかる。ただしこの実験は夏季に行なわれたもの であるが，室温の低い埸合にも，加熱さえ十分なら 价，同様の現象が見られるであるう。

粘度を与えるために，1\%のでん粉を加えて行な った成績を図 3 に，3\%のでん粉を加亲たものを図 4 に示した。これらの図に示されるように粘度のめ る場合には液の上層部と下層部の温度上昇の関係は 真水の場合とまさに反対の様相を示す。これは液の 粘性より対流が阻害されたことを示するのである。 なお $1 \%$ 溶液においては加熱の初期に，3\%溶液に おいては加熱の初期と後期とに両層の温度に混乱が 見られる。この混乱は液の粘度の上䄯により対流が 阻害されて, 突沸現象が起ったことによると考えら れる。なお $3 \%$ 和ける初期の混乱は，1\%のとき とは正反対であることが図に示されているが，これ は同一場所の温度測定が $3 \sim 4$ 分間隔に行なわれて

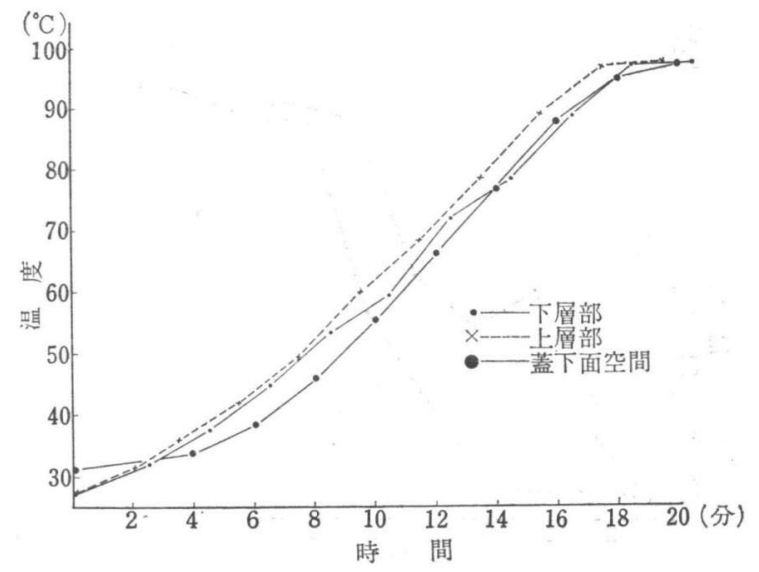

図 2 小鍋, 真水, 液上層, 下層, 液上空間の温度 上昇

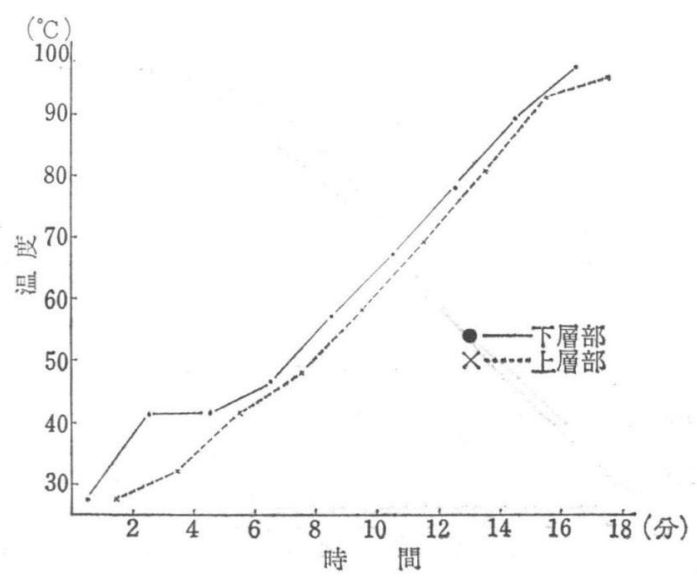

図 3 小鍋, $1 \%$ くず湯, 液上層, 下層の温度上昇

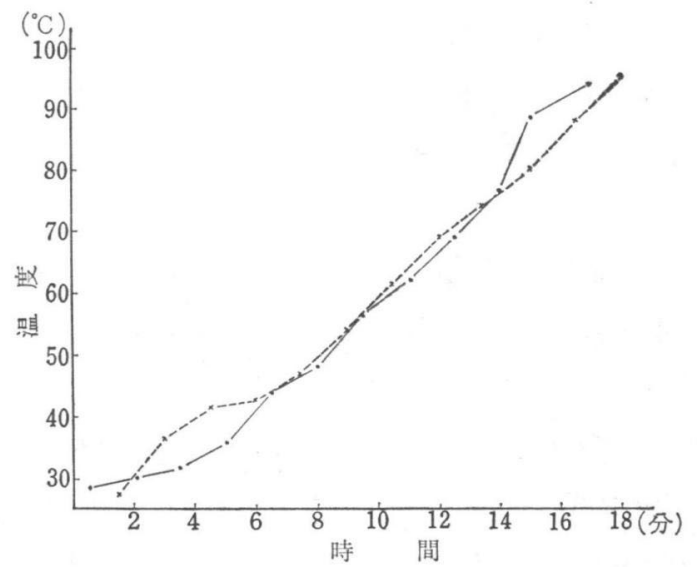

図 4 小鍋, $3 \%$ くず湯, 液上層, 下層の温度上㫒 いるため，3\%の場合には加熱と同時に突沸を生じたということを意味するるのである。 $5 \%$ のでん粉を混ぜ

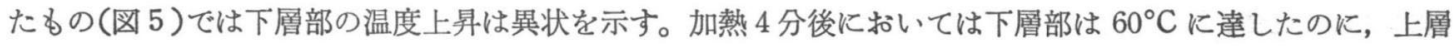




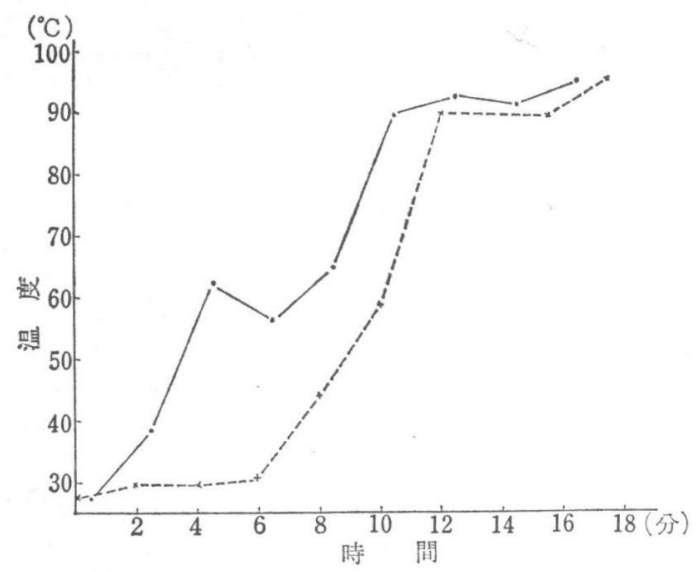

図 5 小鍋，5\%くず湯，液上層，下層の温度 上年

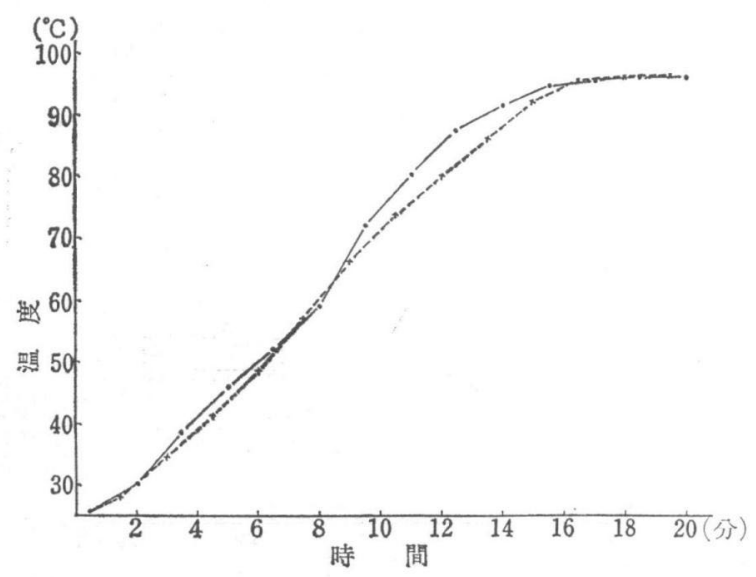

図7 小鍋, 水: コンニャク=1：2, 液上層, 下層の温度上昇

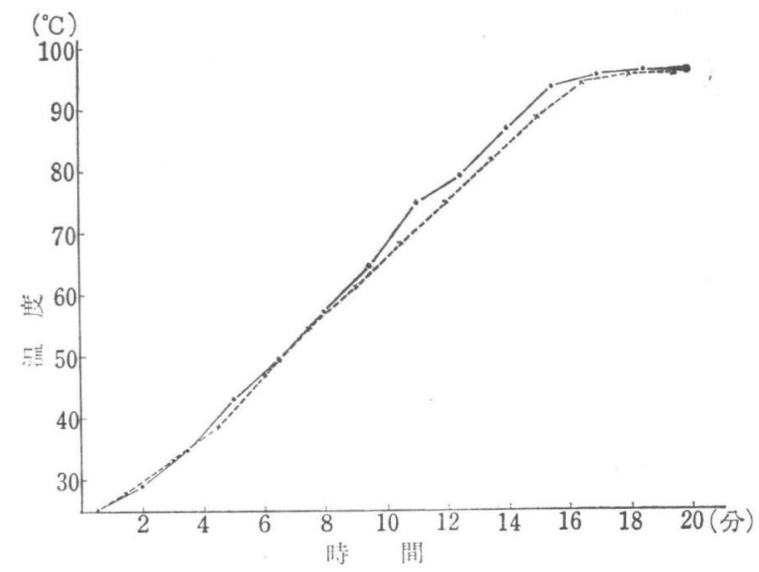

図 6 小鍋, 水: コンニャク = 1：1, 液上層, 下 層の温度上䄯

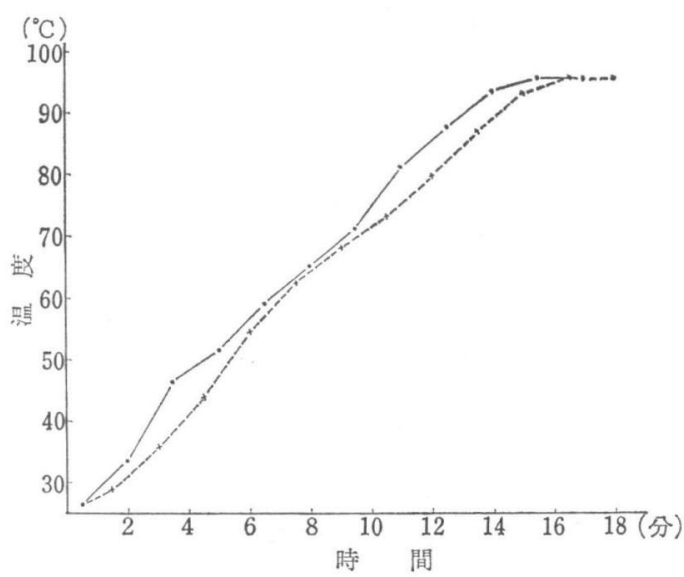

図 8 小鍋, 水: コンニャク $=1: 3$, 液上層, 下層の温度上䄯

部はほとんど初めの温度を示し，その後 6 分に至って下層部の温度は $5^{\circ} \mathrm{C}$ 低下し，同時に上層部の温度は急に 上犁しはじめる。しかも上下層の温度差は $10^{\circ} \mathrm{C}$ 以上に達し, 12 分後に至って両者の温度にほ浪一致を見る。 対流阻害の傾向は 1 3\%のでん粉溶液にも見られたものであるが，3\%までのでん粉溶液と $5 \%$ のでん粉 溶液とでは意物の募汁としての性格が，非常に異なるものであると考克てよいであろう。

b. 加熱される溶液に, 食品が入れられた場合の容器内の温度分有 $:$ 液中に固形の物体が入っていれば, 対 流は阻害されるはずと考劣てこの実験を行なった。物体としては前述の如くコンニャクを用いたが，その結果 を図 6〜8に示す。実験はこの図に示したもの以外にも，水とコンニャクの容積比が，水に対し1.5, 2.5の 2 種についても行なったが，図示することを省略した。

実験の結果は意外にも液中のコンニャクの体積が液の 3 倍に達しても, 液の対流はそれはど影響されず, 前 述の $5 \%$ のでん粉液に拈ける如き，突沸現象は見られなかった。ただ,コンニャク：水比 $1 / 1,2 / 1,3 / 1$ を比 較すると，僅かずつではあるが，比が大きくなるに従って，上下層間の温度差が大きくなる傾向はみられた が，これも $3 \%$ でん粉液の場合と似た傾向を示すにすぎない。以上の結果から液の対流は液中に投入された物 体によって阻害されることは少ないということがわかる。 
B）大鍋を用いる大量調理実験

(1) 実験方法

a. 使用した鍋：直径 $81 \mathrm{~cm}$, 深さ $30 \mathrm{~cm}$ ガス回転金を使用

した。水深 $20 \mathrm{~cm}$ で水の容量は $47 l$ でめった。

b. 温度測定 : 熱電対の感応部の位置は図 9 亿示した。

c. 粘度ある煮汁の作製：小鍋の実験に行なったものと同様で ある。

d. 食品の代りに用いた固形物について：小鍋の場合と異なり，か

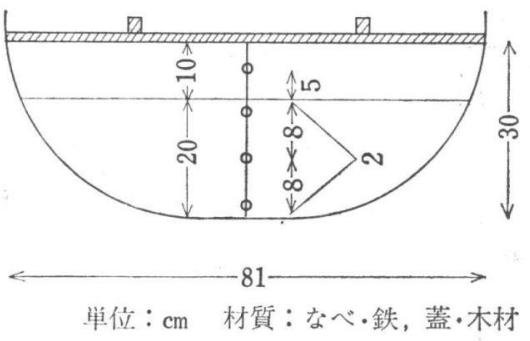

図 9 大鍋実験, 熱電対感応部の 位置 なり大形のものを入れて見る必要があるので，水に溶けず，比重が 1 に近いものとして，庭球の軟式ボールに 水を入れたものを用いた。

(2) 実験の条件

実験は次の上うな条件で行なった。

\begin{tabular}{llcc}
\hline 実験番号 & \multicolumn{1}{c}{ 液体打よび内容物 } & 全容量 $(l)$ & 実験回数 \\
\hline No. 1 & 水道水 & 47 & 2 \\
No. 2 & でん粉 $1 \%$ 溶液 & 47 & 1 \\
No. 3 & でん粉 $3 \%$ 溶液 & 47 & 1 \\
No. 4 & でん粉 $5 \%$ 溶液 & 47 & 1 \\
No. 5 & ボール $0.5:$ 水 1 (容量比) & 30 & 1 \\
No. 6 & ボール $1:$ 水 1 (容量比) & 30 & 1 \\
No. 7 & ボール $2:$ 水 1 (容量比) & 30 & 1 \\
\hline
\end{tabular}

(3) 実験結果

a. 加熱される水溶液の粘度と容器内の温度分布について：実験の結果は図10〜14のようになった。すなわ ち真水の場合, 上層部の温度は直ちに下層部より高くなる。その差は加熱後 20 分に至れば $5^{\circ} \mathrm{C}$ に達し, 25 分 では $5^{\circ} \mathrm{C}$ を超える。しかし28分後には上下の差はなくなる。水の上層部の温度が下層部より高いために，こ の期間は蓋下の温度も下層部よりは高くなる。しかも蓋下の温度は加熱後10分頃までは上層部の水温よりも高 い。しかし $1 \%$ でん粉液では, 上下層の温度差はこのようにはならず，むしろ差は非常に少ない。この場合，

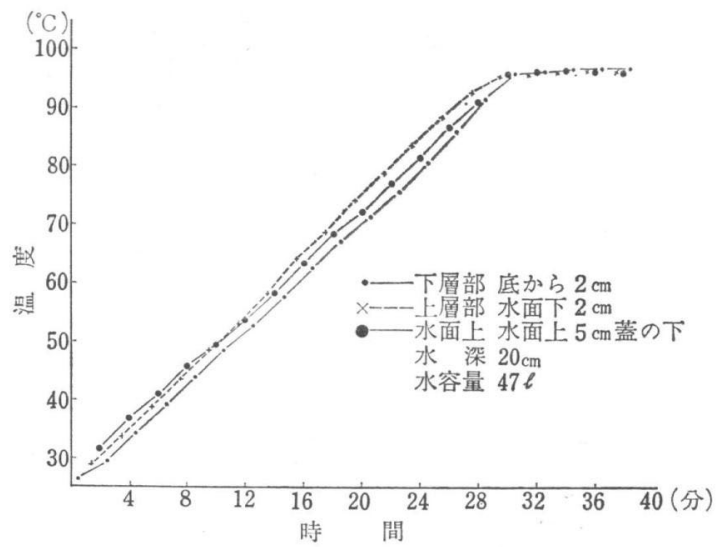

図 10 大鍋，真水，液上層，下層，液上空間の温 度上年

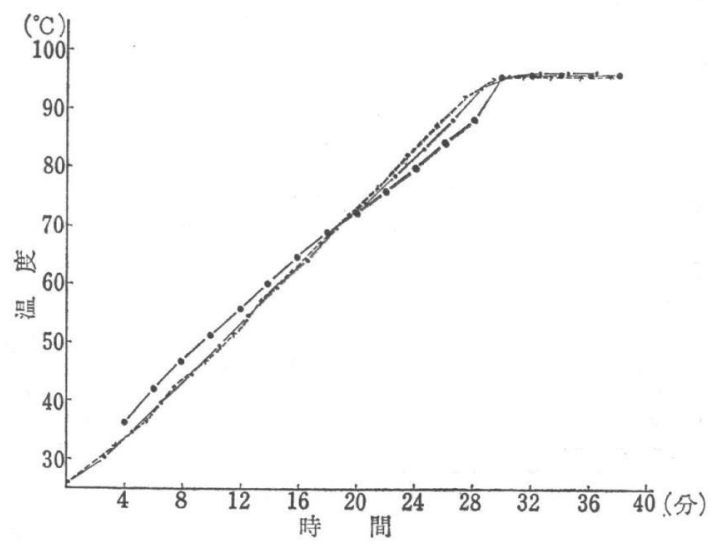

図 11 大鍋，1\%くず湯，液上層，下層，液上空 間の温度上年 


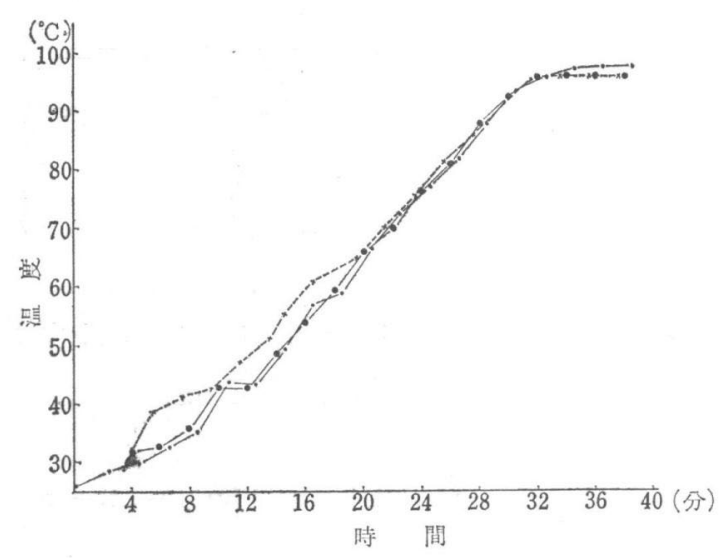

図 12 大鍋, $3 \%$ くず湯, 液上層, 下層, 液上 空間の温度上昇

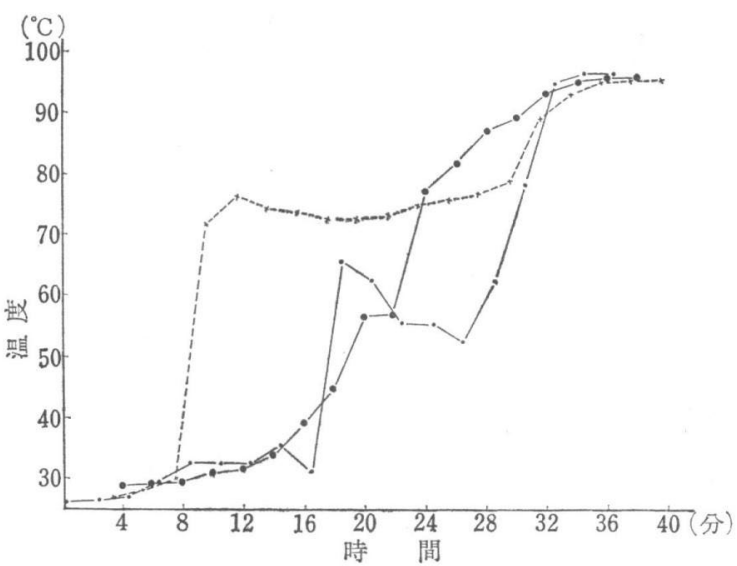

図 13 大鍋，5\%くず湯，液上層，下層，液上 空間の温度上年

蓋下の温度は加熱後20分頃までは上下層部よりもむしろ高い。3\%，5\%のでん粉液では粘度が高くなるた め, 底部に熱の蓄積が起り，そのため突沸現象を見るため，3\%の昜合 4 分頃から，5\%液の場合 8 分後頃か ら, 上層部の温度は突然に上升する。 $5 \%$ の場合, 突沸の起るのが遅れるため, 底部の熱の蓄積も大きく, そ のため発生後は温度の上昇も著しい。上層部の温度が急上升した後, 急に液の対流が発生するため, 底部の温 度は急に低くなる。

実際の加熱調理に際して，上層部の温度が下層部より早く高くなること，蓋下の温度が，初期において上層 部よりさらに高くなっていることなどは, 集団給食などの大量調理に際して, 蓋の利用が重要であることを意 昧することを示するのである。

b. 加熱される水溶液に食品が入れられた場合の容器内の温度分布 : 小鍋についての実験では，食品に代る ベきものとしてュンニャクを用いたが, 大鍋についての実験では, 大型のものを用いる必要があると考えて, 庭 球ボールに水を入れたものを食品の代用として用いることとした。ただこの場合に注意しなければならぬこと は, ボールの表面を作っているゴムの熱伝道率が， $0.31 〜 0.38 \times 10^{-3}$ であるのに反し，食品の熱伝導率2) が

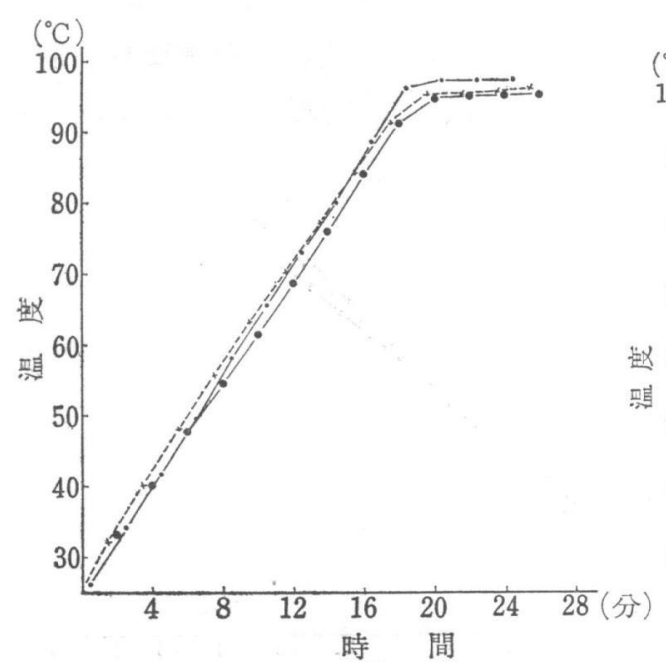

図 14 大鍋, 水 : ボール $=1: 0.5$, 液上層, 下層, 液上空間の温度上年

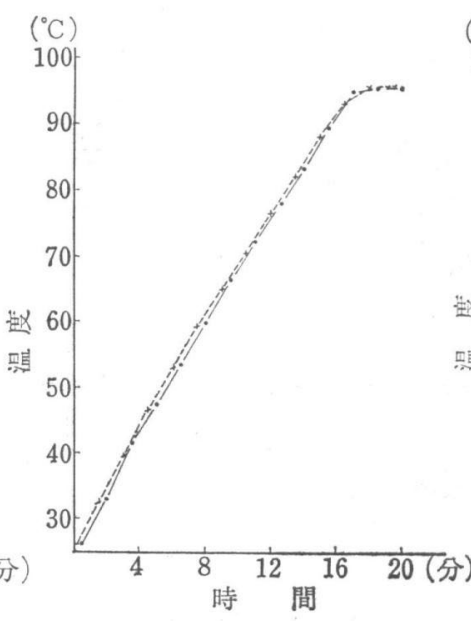

図 15 大鍋，水 $*$ ホル $=1$ : 1 , 液上層, 下層の 温度上昇

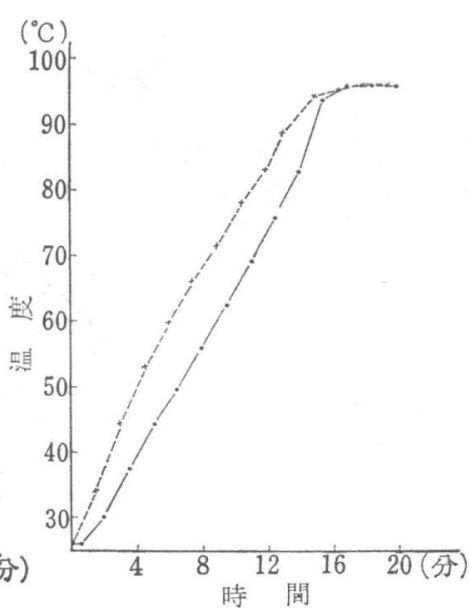

図 16 大鍋, 水: ボール= $1: 2$, 液上層, 下 層の温度上昇 
1. 4 1. $5 \times 10^{-3}$ で約 4 倍であることである。このことは食品を煮る実際の場合に比し，食品の代りに投入 したボールに熱が奪われないため，ボールの外部を満す液温の上昇が，実際の煮物の場合より早くなることを 意味する。実験の結果は図14 16の如くであったが，ボールの占める体積が多くなるに従って，水温の上梨は 急になることを示している。また特にボールの体積比が水量の 2 倍になった図16の場合に，上層の水温はむし ろ下層より高くなっていることを示している。

以上のことから，固形食品が水中にかなり多くの体積を占める場合にも，その相互の間に間腺のある場合に は，水の対流は阻害されないことがわかる。ただし実際の場合には，鍋底に密着した食品が，直接鍋底からの 熱を受けて，密着部が高温となることはあり得るわけで，このような条件は今回の実験条件としては，考慮し ていないるのである。

\section{III 考察ならびに結論}

以上の実験の結果を，実際の調理に際しての問題として考えると，煮汁の対流が速やかな場合には，沸点に 近づくまで，底部の温度は上層部の温度よりも低く，また蓋がしてある場合，液面と蓋との間にある空間も， 液と同一の温度に達していた。このことは煮物の場合，食品の一部が，液上に露出していても蓋さえよくして あるならば，完全に加熱されることを意味している。

また，煮汁に粘度があって液の対流のそこなわれる場合は，底部に突沸の現象が発生して，はじめて液の擋 拌が行なわれて均一な温度に近づくことがわかる。このような現象は，3\%のでん粉液では明らかでなく， 5 \%のでん粉液のときに明瞭に見られるものである。

液の中に固体の塊が存在している通常の煮物のとき, 実験の結果からは, 液の粘度が増加していない限り対 流を妨げることはないことがわかった。それのみならず，鍋の容積が一定の場合には，固形物が多いとそれだ け液量が少なくなるので液の温度の上升は早くなるわけである。一方食品の熱伝導率は小さいので, 食品が多 く入った場合にはよほど静かに加熱しないと液の蒸発のみが起って，食品の加熱は困難になるという現象が起 る。このことは同時に，集団給食の調理では蓋がよくできない場合が多いので，多量の食品を煮る場合，煮汁 を多くして煮ることになってしまうのであちう。この点が，集団給食の煮物と，家庭の煮物との大きなちがい となるのである。

\section{要 約}

集団給食の調理では，煮物をする機会が著しく多いのにもかかわらず，煮物に際して煮汁の熱による対流に ついての測定值はほとんど発表されていない。また一方，煮くずれの原因の一つは，食品の浸透圧とも関係す ると思われるが，この測定值も見られない。本報告は，これらについての実験の結果を述べた。

1. 真水から $3 \%$ \%でん粉溶液までの間では，液の粘度の上昇にもかかわらず，熱の対流に著しい差は見ら れなかった。

2. 煮汁中に，固形物が入っている場合にも対流は阻止されなかった。

3. 蓋の効果として, 蓋と液面との間の空間は, 液の上層の温度とほぼ等しくなることがわかった。

1）東京天文台編纂 : 理科年表文献

2）中浜信子 : 食品の熱伝導度について, 家政学雑誌, 16, 1 (1965) （受付 : 昭和48年 8 月20日） 